\title{
Analysis of the Patterns of Smallholder Farmers' Responses to Production Shocks in Tanzania: The Case of Rufiji, Mbarali and Sumbawanga Districts
}

\author{
Peter Samwel \\ PhD Student \\ University of Dar es Salaam \\ Elliott P. Niboye \\ Associate Professor \\ Institute of Development Studies \\ University of Dar es Salaam
}

\begin{abstract}
This study sought to gain in-depth understanding into smallholder farmers' responses to production shocks in Tanzania. It involved identification of the strategies that smallholder farmers use to cope with production shocks. The study employed mixed research methodology, using primary data collected from six villages in Sumbawanga, Mbarali and Rufiji districts in Tanzania. The findings of the study revealed that there are various strategies that smallholder farmers use in response to production shocks. The strategies include agricultural intensification, diversification of livelihoods activities and migration. Policy implication of this study is that policy makers and other stakeholders should recognize important roles of smallholder farmers' response options in mitigating the adverse impacts of production shocks.
\end{abstract}

Keywords: Smallholder farmers, farmers' responses, agricultural intensification, diversification, migration, coping strategies, rural livelihoods

\subsection{Introduction}

Agricultural production shocks have been receiving an increasing recognition as major challenges facing rural communities. Recent studies on agriculture sector suggest that agricultural production shocks have become a serious threat to smallholder farmers who are estimated to own 70 per cent of all farms in the world (Bates, Kundzewicz, \& Palutik of, 2008; FAO, 2012). However, it should be noted that these shocks are unevenly distributed across and within regions around the world whereby farmers in developing countries have become more vulnerable than those in other regions (World Meteorological Organization, 2009). Within developing countries, the African region is the most vulnerable to agricultural production shocks. Evidence shows that farmers in Africa are highly exposed to production shocks since their livelihoods depend on an increasingly deteriorating natural resource base and on often volatile climatic and market conditions. According to World Meteorological Organization (2009), approximately 70 per cent of Africans or close to 700 million people rely on farming for their livelihoods and over 95 per cent of cultivation in Africa is rain fed. Africans are also particularly vulnerable to production shocks because they have few assets to fall back on and limited risk management strategies (Ellis and Freeman, 2004; Paavola, 2004). Other features include overdependence on natural resource use, poverty, prevalence of diseases, and in some countries, internal conflicts and civil unrests (Ngigi, 2009; Raleigh \& Urdal, 2007).

Production shocks have also been affecting smallholder farmers at community and household levels. Both idiosyncratic and covariant shocks have been posing a threat to farming households in rural Africa. Poor rural infrastructures coupled with other problems such as variable prices of agriculture inputs, poor rural infrastructures, conflicts between farmers and herders, land degradation, crop pests and diseases, droughts and floods have adversely affected farmers and rural households at large (Food and Agriculture Organization [FAO], 2016).

Furthermore, smallholder farmers are exposed to shocks related to human diseases and disabilities, poor policy interventions and crime related attacks that affect agriculture production. Over the last three decades, HIV/ AIDS has adversely affected agricultural production in rural Africa. Households affected by HIV/AIDS tend to divert their resources and time to caring of the sick at the expense of farm work (FAO, 2016; Kalinda, 2014). In addition, crimes such as theft of agriculture inputs and products tend to affect agricultural activities. For instance, loss of oxen due to theft adversely affects farm activities because households cannot cultivate their fields in a timely manner (Kalinda, 2014; Kessy, 2005 cited in FAO, 2016). 
The importance of agriculture and its sensitivity to social, economic, climate and environmental shocks have compelled farmers to adopt and implement various options in response to those shocks. The list of response options is too long but the emphasis is that depending on the nature of stress and their socio-economic contexts, smallholder farmers choose from options they have, and implement particular strategies to respond to specific risks and vulnerabilities (Ndaki, 2014). Below, Artner, Siebert \& Sieber (2010), for example, mention a dozen of both on-farm and off-farm strategies employed by farmers in responding to climate shocks in Africa. Jain and Parshad (2007) mention crop diversification, plot diversification and mixed farming. Other commonly cited strategies include irrigation farming, changing of planting dates, multiple cropping and integration of livestock (Acquah \& Onumah, 2011; Hassan and Nhemachena, 2008).

In Tanzania, agriculture and vulnerability are closely linked due to the location of the smallholder farmers who mainly depend on agricultural sector despite of their attempts to diversify livelihoods options. Data shows that about 75 per cent of Tanzanians live in rural areas and agriculture employs about 70 percent of total labour force (National Bureau of Statistics [NBS], 2014). Therefore, agricultural production vulnerabilities are likely to have profound impacts not only to farming households but also to other rural dwellers.

A wide range of literature on responses to stresses and shocks acknowledge that farming communities have been responding to production shocks for decades (Agrawal and Perrin, 2008; Kangalawe, 2012; Below et al. 2010). The increasing vulnerability of agriculture to production shocks and the need for effective policy responses has attracted increasing research interests on farmers' response options in the face of production shocks. Based on this background, the study in which this manuscript is based aimed at identifying smallholder farmers' responses to production shocks.

\subsection{Methodology}

This study employed mixed research methodology. Concurrent mixed design was used where by qualitative and quantitative data were collected at the same time during the study and the information was integrated in the interpretation of the overall results. Qualitative and quantitative data were collected concurrently to best understand smallholder farmers' perceptions and awareness of agricultural production risks and shocks. The mixed methodology was chosen in order to overcome the limitation of using one method and to allow a comprehensive understanding of the research problem.

The target population for this study were the smallholder farmers in Rufiji, Mbarali and Sumbawanga districts in Tanzania. Sample of 510 respondents was chosen from six villages in those three districts of which all were the heads of households. Three sampling techniques were used: purposive sampling, simple random sampling and snowball sampling. While purposive sampling was used to sample the villages, simple random sampling and snowball sampling were used to sample the respondents for the study.

\subsection{Results and Discussion}

This section presents the findings of the study on the patterns and drivers of smallholder farmers' responses to production shocks. The section is divided into two parts: the first part examines smallholder farmers' responses to production shocks while the second part focuses on the identification of the driving factors for the choice of those response options.

\subsection{Smallholder Farmers Responses to Production Shocks}

The findings of the study revealed that smallholder farmers various ways to respond to production shocks. The response options have been categorized into three broad categories adopted from Ellis (2000). These broad categories are agricultural intensification, livelihood diversification and migration.

\subsubsection{Agricultural Intensification}

Literature on rural livelihoods has identified agricultural intensification as one of the livelihoods strategies that rural household pursue in response to vulnerability contex. The results of this study shows farmers in the study area have been involved in agricultural intensification as one of their responses to agricultural production vulnerabilities. Agricultural intensification refers to 'increased average inputs of labour or capital on a smallholding, either cultivated land alone, or on cultivated and grazing land, for the purpose of increasing the value of output per hectare (Tiffen et al., 1994). According to Carswell (1997) the processes associated with agricultural intensification include an increased (per fixed unit of land) frequency of cultivation, an increase in labour inputs, or a change in technologies. The common onfarm practises associated with agricultural intensification includes increased use of natural or artificial fertilisers, improved seeds, animal traction, mechanisation, multi cropping, or series/relay-cropping and changes to the landscape such as irrigation, or soil conservation measures would suggest that intensification was occurring (Soini, 2005). 
Field survey found that crop diversification was commonly used by smallholder farmers to respond to production shocks. Data indicated that about 92 percent of the farmers were involved in cultivation of more than one crop although rice and maize continue to dominate agriculture production in the study area. This is consistent to the findings of Ibrahim et al., (2009) on crop and income diversification among farming households in a rural areas of north-central Nigeria. The author reported that crop and income diversification were strategies that were essential for reducing rural poverty among farming households. Nevertheless the observation that majority of the farmers are involved in crop diversification is contrary to the findings of Simwambana (2007) who found that most farmers in Zambia did not diversify in terms of crop production. This may be accounted by the fact that the study narrowed its focus to cassava and sweet potatoes whilst ignoring other crops like groundnuts and millet, among others.

Regarding the crops the study shows that crop diversification pattern involved cultivation of maize or rice with other crops. Other crops which were planted together with the major crops include beans, groundnuts, sunflower, cassava and sorghum. A few individual farmers also specialized in crops like sweet potatoes or wheat or in vegetables like Chinese, cabbage or tomatoes. Household analysis indicated that farmers in Chumbi and Mohoro have fewer crop varieties in comparison with the other villages. In Kaengesa, farmers seem to have the most diverse cropping system with some few cattle, some pigs, goats and poultry. They have most land per household and plant a variety of crops and forest trees.

Table 1: Crop Diversification Combinations by Households in 2015/2016 Season

\begin{tabular}{|c|c|c|c|c|c|c|}
\hline \multirow[b]{2}{*}{ Crops } & \multicolumn{6}{|c|}{ Percentage of Households } \\
\hline & Chumbi & Mohoro & Igumbilo & Uturo & Kaengesa & Mpui \\
\hline Rice only & 6 & 6 & 14.3 & 23.8 & 2.4 & 1.2 \\
\hline Maize only & 8.3 & 7.1 & 13.1 & 13.1 & 13.1 & 14.1 \\
\hline Maize and rice & 14.3 & 13.1 & 34.5 & 25 & 16.7 & 17.6 \\
\hline Maize and beans & 0 & 0 & 13.1 & 13.1 & 15.5 & 14.1 \\
\hline Maize and cassava & 14.3 & 14.3 & 0 & 0 & 7.1 & 8.2 \\
\hline Maize and sunflower & 0 & 0 & 2.4 & 3.6 & 7.1 & 7.1 \\
\hline $\begin{array}{l}\text { Maize, beans and } \\
\text { sunflower }\end{array}$ & 0 & 0 & 2.4 & 1.2 & 8.3 & 7.1 \\
\hline Maize and millet & 11.9 & 13.1 & 0 & 0 & 2.4 & 3.5 \\
\hline Maize, rice and cassava & 13.1 & 11.9 & 7.1 & 7.1 & 4.8 & 1.2 \\
\hline Maize, millet and cassava & 9.5 & 10.7 & 0 & 0 & 0 & 3.5 \\
\hline Maize, cassava and & & & & & & \\
\hline groundnuts & 9.5 & 10.7 & 0 & 0 & 0 & 2.4 \\
\hline Maize and groundnuts & 8.3 & 7.1 & 9.5 & 9.5 & 15.5 & 11.8 \\
\hline Other crop combinations & 4.8 & 6 & 3.6 & 3.6 & 7.1 & 8.2 \\
\hline Total & 100 & 100 & 100 & 100 & 100 & 100 \\
\hline
\end{tabular}

Source: Field Survey, 2016

Crop rotation is an essential mechanism when it comes to risk management, especially if the crops are subjected to soilborne pests and diseases. It involves a series of crops cultivated in the same field following a defined order. Crop rotation has the potential to break the life cycles of insect pests and diseases that may affect crop growth and productivity (Altieri \& Nicholls, 2005). Also, the addition of plant residues to the soil through crop rotation tends to stimulate the activities of different micro-organisms and improve soil quality (Gliessman, 2007).

The findings of the study indicated that crop rotation was a commonly used by smallholder farmers to respond to declining soil fertility associated with land degradation. Smallholder farmers were well informed about the impacts of continuous mono-cropping on soil fertility. Probably this was a result of local knowledge acquired through long time experience in farming and through transmission of knowledge from one generation to another. During the interviews it was revealed that crop rotation has been practiced from the time immemorial. When interviewed, the farmers explained that the method has been practiced since the time of ancestors. However, in recent years the method has been adopted by many farmers due to massive land degradation associated with mono-cropping.

Field data indicated that about 80 percent of the farmers were practicing crop rotation. However, Uturo village had the smallestproportion of farmers who practiced crop rotation. One reason explaining this observation was that some of the respondents in Uturo village specialized in irrigated rice farming at Uturo irrigation scheme. Those farmers mostly cultivated on hired plots with short-term lease contracts ranging from 1-3 years, thus they had no motivation for soil conservation. 
Several other studies have shown that insecure land tenure, characterized by short-term lease contracts, does not contribute to soil conservation (Fraser, 2004; Praneetvatakul et al., 2001; Soule et al., 2000). Crop rotation was therefore practised mostly by land owning farmers, who had the long-term interest in the quality of the soil. Contrary, tenants mostly engaged in practices to maximize short term gains depending on the length of the lease contract with the land owner.

Figure 1: Common Forms of Crop Rotation in the Study Area

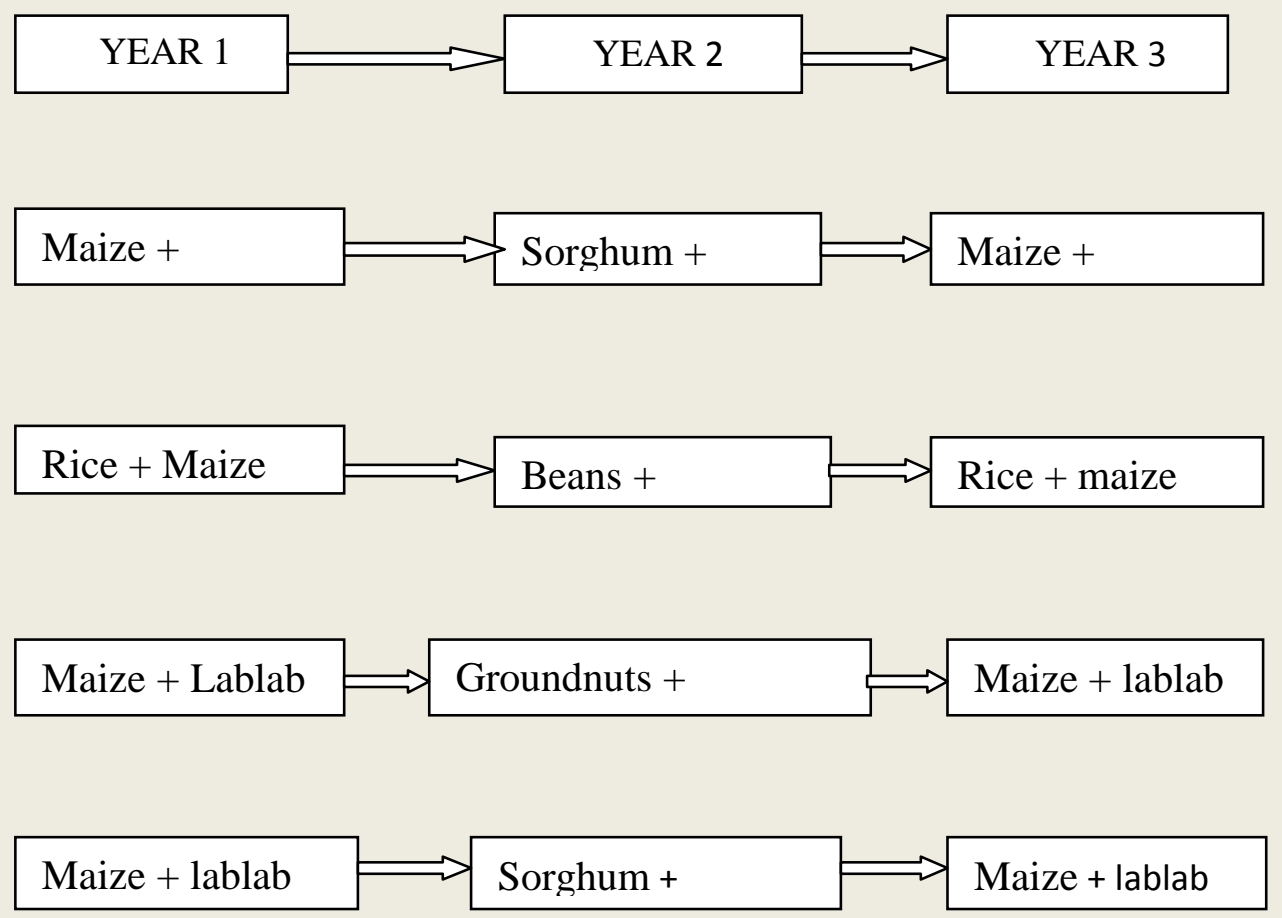

As shown in figure 1 above, smallholder farmers commonly practiced cereal-legume rotations. Maize-groundnutmaize rotation was the most common rotation in Mohoro and Chumbi villages while in Kaengesa and Mpui villages maize is rotated with sorghum or soybeans. In Igumbilo and Uturo rice-beans-rice rotation is very popular among the farmers. Other crop sequences include maize-cowpeas-maize and maize-lablab-maize. In some cases intra-seasonal crop rotation was practised by some few farmers. This was the case for the farmers who cultivated their plots twice a year. In this practise, farmers divided their farm lands into two or three (depending on the number of crops) and grew the main crop (rice or maize) in the main farming season (February-June) and change the crops during the minor farming season (July-October).

Given the risky environment in which farming households operate, farmers in the study area try to mitigate the impacts of production shocks by allocating their resources to different fields (plots). Having multiple plots helps farmers to avoid some production shocks that affect a small geographical area. During the survey, it was established that in villages like Chumbi, Mohoro, Igumbilo and Uturo where there have been incidences of vermin and livestock feeding on crops, farmers prefer to own multiple plots in different locations. Farmers had opinion that by owning multiple plots you could have enough food for your household even if one of your plots is fed by the livestock or attacked by pests and vermin.

Most farmers tried to keep these plots in different places in the same village or nearby villages. About 51.2\% of farmers in Mohoro and Chumbi were traveling up to $5 \mathrm{~km}$ from their homestead to clear new land for cultivation while this number was $47.6 \%$ and $47.1 \%$ in Kaengesa and Mpui respectively. In Igumbilo and Uturo some farmers were traveling over $5 \mathrm{~km}$ mostly to hire a land rather than clearing a new land. This reflects lack of virgin land for further expansion of crop cultivation and increased competition for land. Household interviews also confirmed that compared to other villages, farmers in Igumbilo and Uturo travel a considerably longer distance from their homesteads to their fields. Sometimes these farmers used bicycles or motorcycles popularly known as bodaboda as a means of transport to their fields. 
Despite its perceived benefits, ownership of multiple plots was associated with the increase of the distance from the homesteads to the fields (Shambas). It was observed that about $50 \%$ of the farmers had at least one plot located 5 or more Kilometres away from the homestead. Longer distances from homestead to the farms tend to affect farming and land management practices. During field surveys it was observed that most of the fields in Igumbiro and Uturo were well-maintained and had at least some kind of soil conservation measure in place partly because they were located close to homesteads. Less walking distance from homesteads to the farms facilitates transportation of manure to the farm and encourages more intensive farming, since the option for expansion is limited (Dejene et al., 1997). In Chumbi and Mohoro where farms were located far from homesteads, majority of the farmers did not practise soil conservation measures.

In response to prolonged rainfall variability some farmers in the study area resort to small scale irrigation. Many of the respondents $(62 \%)$ indicated that irrigation farming is less risky than the rainfed agriculture. Indeed, irrigation farming among small-holders can substantially reduce crop failure due to meteorological drought (Enfors \& Gordon, 2008; Laube et al., 2012). Field data revealed that small-scale irrigation facilities are increasingly being used by households, especially those in Chumbi, Mohoro, Igumbilo and Uturo villages. During household interviews participants explained that using irrigation as a way of coping with rainfall variability has assumed greater importance in the last two decades, because unreliable rainfall has become predominant. For instance, without irrigation facilities, farming is mostly possible for one season in a year whilst some years back households could farm twice a year.

While in Chumbi and Mohoro villages the practice of irrigation is of primitive type, Uturo village has a relatively improved irrigation system. An interview with AEO revealed that given the favourable conditions in Uturo village, there has been a long tradition of irrigation, based originally on farmer-constructed canals. Over the last two decades there have been various efforts from the government and other stakeholders to improve these systems, primarily through the provision of concrete structures and canals. As a result of these efforts, a construction of a concrete canal was completed in 2008. This canal supplies water to smallholders in Uturo scheme. Conversely, in Chumbi and Mohoro villages irrigation system involves the use of temporary diversion structures across the beds of rufiji river streams and earth canal flowing into the farms.

Field survey indicated that nearly half $(49.5 \%)$ of the irrigating farmers harvest at least twice a year whereas $(50.5 \%)$ of irrigating households harvest once a year due the fact that their farms were located far from water sources. Conversely, 95 percent of non-irrigating households harvest once a year due to unreliable rainfall. The major crops grown in the irrigated farms includes rice and maize which are major crops followed by vegetables, potatoes, beans and onions.

Evidence in the field revealed that there has been an increase in the number of farmers using improved seeds as a way of reducing the impacts of land degradation, rainfall variability as well as pests and diseases. It should be noted that some improved seeds are better suited to mitigate the impacts of production vulnerabilities because they have characteristics such as drought tolerance, high yielding and early maturity (FAO, 2009). Drought tolerance varieties can survive long dry spells associated with rainfall variability that has become a common feature of agriculture production. In addition, some of the improved seeds are disease tolerant and thus they are usefull in areas affected by diseases ${ }^{1}$.

In the study villages, smallholder farmers reported planting early maturing varieties of maize, beans, millet and sorghum. During the household interviews, farmers explained that they prefer early maturing varieties as a way of adapting to rainfall variability and reducing the impacts of pests and diseases. According to them, if there is early cessation of rain season drought-escaping varieties would have passed the most critical stages of their development such as flowering which requires an appreciable amount of water to produce a good harvest. Also, by maturing earlier, these varieties reduce the risk associated with pests and diseases because they mature earlier before pest or disease attack.

Field survey revealed that some farmers were responding to land degradation by using artificial fertilizers (table 2). The use of artificial fertilizers was motivated by the declining soil fertility associated with land degradation and thus application of fertilizers was meant to overcome the problem. Despite the use of chemical fertilizers some smallholder farmers believed that chemical fertilizers resulted into side effects such as crop failures and plant wilting. This perception probably arises as a result of increased soil acidity due to use of inorganic fertilizers, particularly nitrogenous fertilizers which leads to reduced or non-availability of nutrient elements to the crop.

\footnotetext{
${ }^{1}$ For instance, improved rice varieties such as kalalu and mwangaza are resistant to Rice Yellow Mottle Virus (RYMV) while improved bean varieties like Pesa and Mshindi are resistant to Bean Common Mosaic Virus (BCMV).
} 
Table 2: Distribution of Households Using Artificial Fertilizers

\begin{tabular}{|lll|}
\hline Village & Number of Households & Percent $(\mathbf{N}=240)$ \\
\hline Mohoro & 21 & 8.8 \\
Chumbi & 24 & 10 \\
Igumbilo & 48 & 20 \\
Uturo & 48 & 20 \\
Kaengesa & 50 & 20.8 \\
Mpui & 49 & 20.4 \\
Total & 240 & 100 \\
\hline
\end{tabular}

Source: Field Survey, 2016

\subsubsection{Diversification of Livelihoods Activities}

The findings of this study indicated that as part of the efforts to cope with production vulnerabilities and shocks, farming households have chosen to diversify their income sources into non-farm income sources while retaining their cropping activities. During household interviews farmers reported engaging in non-farm economic activities such as petty trading, motorcycle transport services ${ }^{2}$, fishing, and charcoal production to supplement agricultural activities. This diversity of activities is illustrated in table 3, which depicts the livelihood portfolio for farming households in the study area. However, these non-farm economic activities should be seen as complementary activities as crop production was the major occupation for the sample households. Indeed diversification of livelihood activities may actually result in increased agricultural earnings because by earning non-farm income, farmers may be able to access agricultural inputs like improved seeds and fertilizers.

The findings in table 3 below show that smallholder farmers in the study area were engaging in multiple non-farm livelihood activities. Selling of livestock and poultry was the most dominant activity in the study area. Data show that selling of livestock and poultry was most common in Mohoro village (26.2\% of the respondents) and least common in Uturo village. Findings of the study indicated that most of the farmers owned goats, pigs and poultry while few of them owned cattle. In most cases these animals were attached or hover around the compounds and feed from what they are offered. Most cooking residues such as cassava and fruit peelings are transformed into feed for these animals. Farmers reported that sales of animals depended on the nature of the need, and they started by selling poultry before selling large animals thus selling of poultry dominated in the study villages as compared to sales of livestock.

Table 3: Non-farm Livelihoods Activities Undertaken by Sample Households

\begin{tabular}{|lllllll|}
\hline & \multicolumn{2}{l}{ Percentage of Households } & & & \\
Livelihood Activities & Chumbi & Mohoro & Igumbilo & Uturo & Kaengesa & Mpui \\
\hline No diversification activity & 4.8 & 4.8 & 2.4 & 1.2 & 1.2 & 2.4 \\
Petty trade and kiosks & 21.4 & 25 & 22.6 & 20.2 & 13.1 & 11.8 \\
Food vendor & 4.8 & 3.6 & 7.1 & 9.5 & 8.3 & 7.1 \\
Salaried employment & 2.4 & 3.6 & 4.8 & 7.1 & 3.6 & 4.7 \\
Masonry & 2.4 & 1.2 & 3.6 & 4.8 & 2.4 & 3.6 \\
Tailoring & 2.4 & 2.4 & 2.4 & 3.6 & 3.6 & 2.4 \\
Fishing & 8.3 & 4.8 & 0 & 0 & 0 & 0 \\
Selling of livestock and poultry & 26.1 & 26.2 & 16.7 & 14.3 & 26.2 & 23.5 \\
Casual labour & 3.6 & 4.8 & 14.3 & 16.7 & 25 & 22.4 \\
Bicycle repairing & 3.6 & 1.2 & 1.2 & 0 & 2.4 & 0 \\
Weaving & 2.4 & 1.2 & 0 & 1.2 & 1.2 & 1.2 \\
Charcoal burning & 8.3 & 8.3 & 0 & 1.2 & 1.2 & 2.4 \\
Selling beer and local brew & 1.2 & 2.4 & 8.3 & 7.1 & 4.8 & 5.9 \\
Carpentry & 2.4 & 2.4 & 4.8 & 3.6 & 1.2 & 2.4 \\
Motorcycle transport Service & 6 & 6 & 9.5 & 7.1 & 14.3 & 12.9 \\
Others & 8.3 & 7.1 & 8.3 & 9.5 & 4.8 & 5.9 \\
\hline
\end{tabular}

Source: Field Survey, 2016

\footnotetext{
${ }^{2}$ Motocycle transport services are popularly named bodaboda.
} 


\subsubsection{Migration}

Migration of household members has long been part of the livelihood portfolio of farming households in rural Tanzania (Madulu, 1998; Mbonile, 1993; Mung'ong'o, 1998). It is now recognised that migration is one of the strategies that rural households including farmers use in response to shocks and stress (Guzman et al., 2009). Many of these movements are temporary and seasonal coping strategies. They mostly involve a few household members rather than a whole household. Under certain conditions migration may have some sort of permanency, and involve a whole household.

The decision to migrate is usually influenced by interaction of numerous pull and push factors such as economic, political, environmental and social conditions. In each specific situation, these interactions can increase or decrease migration (Piguet et al., 2011; Renaud et al., 2011). Thus it is difficult to separate the underlying causes of such migrations as farmers respond to multiple opportunities and threats at a time (De Bruijn \& Van Dijk, 2003; Painter et al., 1994). However as far as this research is concerned it is important to note that migration decision is partly informed by the agricultural production shocks in rural areas.

FGDs and household interviews suggested that migration is one response to agricultural production shocks used by the farmers in the study area. Indeed, farmers generally traced back the rise of migration to the increase in the incidence of crop failure, and thus indirectly to problems like rainfall variability, land degradation, as well as pests and diseases just to mention a few. Farmers claimed that they are less likely to migrate in future if adequate, predictable and reliable income is generated from agriculture. It is also important to note that the linkages between production stresses and shocks and migration, however are not linear. For instance, deteriorating rainfall conditions tend to increase rural-urban migration in Mali, however, during the 1983-85 droughts, affected farmers did not migrate to urban areas (Foresight, 2011).

During the survey, all members sharing the same residence and kitchen were defined as belonging to the household and any member who temporary lives outside the village was denoted as migrant. Out of 510 farming households, 251 (49.2\%) households indicated that they have at least one migrant (table 4). In addition, more than half (50.2\%) of these 251 households have only one migrant, while the rest have two or more migrants.

Table 4: Incidence of Migration in Sample Villages

\begin{tabular}{|lll|}
\hline Village & $\begin{array}{l}\text { Number of households with at } \\
\text { least one member migrating }\end{array}$ & Percent $(\mathbf{N = 2 5 1})$ \\
\hline Mohoro & 58 & 23.1 \\
Chumbi & 55 & 21.9 \\
Igumbilo & 37 & 14.7 \\
Uturo & 31 & 12.4 \\
Kaengesa & 34 & 13.6 \\
Mpui & 36 & 14.3 \\
Total & 251 & 100 \\
\hline
\end{tabular}

Source: Field survey, 2016

The findings above show that the highest rates of migration were seen in Mohoro and Chumbi villages where 23.1\% and $21.9 \%$ of households had at least one member migrating. These villages are located less than 200 kilometres from the commercial city Dar es Salaam and their agricultural potential is not properly utilized. Farming is the mainstay of the economy in these villages and there are few opportunities outside casual labouring. These might be possible reasons explaining high migration rates in Chumbi and Mohoro villages. Consistent to dominant perceptions on migration, there was outmigration from all sample villages.

The relationship between cropping seasons and migration was observed in all sample villages, where most outmigration takes place between July and September, after the harvesting season. Due to temporary nature of migration, most migrants return as the new cropping season starts between November and January. This pattern of migration featured in all study villages. It is a pattern that makes use of idle labourers during agricultural off-seasons to provide additional income that will contribute, inter alia, to mitigating the adverse impacts of production shocks. Narratives from household interviews indicated that most of migrant farmers find it extremely difficult to obtain employment in the formal sector because of their lack of skills and low educational levels. Once in their destinations, majority of them mostly work as labourers in other people farms, bar maids, housekeepers, petty traders, bus touts (locally named wapiga debe) and other forms of casual labour. Much of the literature on migration suggests that it is predominantly men who migrate (Antwi-Agyei, 2012; Pauline, 2015; Tacoli, 2011). But in the study area, household members were found to migrate in various combinations: men only, women only, children only, men and women as well as children and adults (men, women or both). 
Even within villages, some households had more men migrating whereas others had more women. Gender analysis indicated that there are marked differences in the gender composition of migration between Chumbi and Mohoro villages on the one hand and the rest of the villages on the other. While in Mohoro and Chumbi villages the majority of migrants were females and children who have just completed primary education, in the other villages such as Kaengesa and Mpui migration involved predominantly youth and adults of all sexual categories.

Remittances sent by migrants constitute a complementary source of income which plays an important role for the livelihoods of other household members. Its role is particularly important during the slack (bad) agricultural season in that it prevents some adverse shocks that households would experience without remittances. Narratives from FGDs and household interviews indicated that remittances are generally used to satisfy the basic household needs such as food, clothes, heath services, school expenditures, and inputs for farming.

\section{Conclusion}

The purpose of this research was to examine the methods used by smallholder farmers in response to production shocks in Tanzania. Three districts namely Rufiji, Mbarali and Sumbawanga were used as case studies. The findings of the study revealed that smallholder farmers use both agricultural intensification, diversification of livelihoods activities and migration as the methods of responding to production shocks. These findings themselves are not new with regard to the general theoretical and conceptual literatures about risk management strategies used by smallholder farmers, but the study is new in the context of study areas as it has particularly brought to light issues of how smallholder farmers survive amidst production shocks that characterize smallholder farming. Policy implication of the study is that policy makers should find better ways of enabling smallholder farmers to adopt coping strategies in a meaningful and sustainable way. However, there is one important research gap to be filled. The current study has identified three broad categories of response strategies namely agricultural intensification, income diversification and migration. It is apparent from this study that more widespread and rigorous research is needed to assess these alternative strategies and come up with the most suitable ones based on local contexts. It is often believed that local, contextual information is better than country level data as vulnerability differs significantly across socio-economic and ecological contexts.

\section{Acknowledgements}

This article is based on the research conducted in fulfillment of the requirements for the Doctoral degree at the University of Dar es Salaam, Tanzania. The research was financially supported by the Dar es Salaam University College of Education (DUCE) and Higher Education Students' Loans Board (HESLB) of Tanzania. The authors acknowledge all institutions and individuals that supported this study.

\section{References}

Acquah-de Graft, H., \& Onumah, E. (2011). Farmers' perceptions and adaptations to climate change: An estimation of willingness to pay. Agris, 3(4), 31-39.

Antwi-Agyei, P. (2012). Vulnerability and adaptation of Ghana's food production systems and rural livelihoods to climate variability ( $\mathrm{PhD}$ thesis). Retrieved from http://etheses.whiterose.ac.uk/5044/1/AntwiAgyei_P_Earth\%20\%26\%20Environment_PhD_2012_PDF.pdf

Asefa, T., Tanner, D., \& Bennie, A. (2004). Effects of stubble management, tillage and cropping sequence on wheat production in the south-eastern highlands of Ethiopia. Soil and Tillage Research, 76, 69-82.

Asian Development Bank. (1999). Developing Rural Financial Markets in Asia. What has been learned? Vol. 2005. Asian Development Bank.

Assefa E., Hans-Rudolf, B. (2016). Farmers' perception of land degradation and traditional knowledge in southern Ethiopia: Resilience and stability. Land Degradation and Development, 27(6):1552-1561.

Bates, B. C., Kundzewicz, Z. W., Wu, S. \& Palutikof, J. P. (Eds) (2008) Climate change and water (Technical Paper). Retrieved from the Intergovernmental Panel on Climate Change website: https://www.ipcc.ch/pdf/technicalpapers/ccw/frontmatter.pdf

Below, T., Artner, A., Siebert, R \& Sieber, S. (2010). Micro-level Practices to Adapt to Climate Change for African Small-scale Farmers A Review of Selected Literature (IFPRI Discussion Paper No. 00953). International Food Policy Research Institute.

Berg B. L. (2004). Qualitative research methods for the social sciences (5 $5^{\text {th }}$ ed). Califonia: Pearson Education, Inc.

Bezabih, M. S. Di Falco, \& Yesuf, M. (2011). Farmers' response to rainfall variability and crop portfolio choice: Evidence from Ethiopia. Retrieved from http://www.rff.org/files/sharepoint/WorkImages/Download/EfD-DP11-10.pdf 
Bielders, C. L., Alvey, S., \& Cronyn, N. (2001). Wind erosion: the perspective of grass-roots communities in the Sahel. Land Degradation \& Development 12(1): 57-70.

Ellis, F. (2000). The Determinants of Rural Livelihood Diversification in Developing countries. Journal of Agricultural Economics 51 (2): 289-302.

Ellis, F., \& Freeman, H.A. (2004). Rural Livelihoods and Poverty Reduction Strategies in Four African Countries. Journal of Development Studies, 40 (4), 1-30.

Food and Agriculture Organization. (2012). Coping with the food and agriculture challenge: smallholders' agenda. Preparations and outcomes of the 2012 United Nations Conference on Sustainable Development. Rome: FAO.

Foresight Project (2011). Migration and Global Environmental Change: Future Challenges and Opportunities, Retrieved from: https://www.gov.uk/government/ uploads/system/uploads/attachment_data/files/287717/111116-migration-and-global-environmental-change.pdf.

Hassan, R., \& Nhemachena, C. (2008). Determinants of African farmers' strategies for adapting to climate change: Multinomial choice analysis. African Journal of Agricultural and Resource Economics, 2(1), 83-104.

Kangalawe, R. Y. M. (2012). Food security and health in the southern highlands of Tanzania: A multidisciplinary approach to evaluate the impact of climate change and other stress factors. African Journal of Environmental Science and Technology 6(1): 50-66.

Madulu, N.F. (1998). Changing Lifestyles in Farming Societies of Sukumaland: Kwimba District, Tanzania (African Studies Centre Working Paper 27: 40.) Dar es Salaam: Institute of Resource Assessment and Leiden University.

Mbonile, M.J. (1993). Migration and structural change in Tanzania: The case of Makete District (Unpublished Doctoral Thesis). University of Liverpool, United Kingdom.

Mung'ong'o, C. G. (1998). Coming full circle: Agriculture, non-farm activities and the resurgence of out-migration in Njombe district, Tanzania (ASC working paper no. 26). Dar es Salaam: Afrika-Studiecentrum, Leiden, Institute of Resource Assessment, Dar es Salaam.

National Burea of Statistics. (2014) Basic Demographic and Socio-Economic Profile Report Tanzania Mainland. Dar es Salaam: National Bureau of Statistics.

Ngigi, S.N. (2009). Climate change adaptation strategies: Water resources management options for smallholder farming systems in Sub-Saharan Africa. New York: The MDG Centre for East and Southern Africa, the Earth Institute at Columbia University.

Paavola, J. (2004). Livelihoods, Vulnerability and Adaptation to Climate change in Morogoro Region, Tanzania (Working Paper EDM, No.04). Retrieved from https://www.econstor.eu/bitstream/10419/80286/1/47788802X.pdf.

Raleigh, C., \& Henrik, U. (2007). Climate change, environmental degradation and armed conflict," Political Geography 26(6): 674-694.

World Meteorological Organization (2009). Improving weather monitoring in Africa. Retrieved from http://www.wmo.int/pages/publications/.

Wye, C. (2003). Overcoming Informational constraints: Improving horticultural marketing and technical information flows to smallholders, literature review. London: Imperial College.

Yehuala, S. (2008). Determinants of smallholder farmers access to formal credit. A case of Metema Woreda, North Gonder, Ethiopia (Masters thesis). Retrieved from https://cgspace.cgiar.org/bitstream/handle/10568/691/Thesis_YehualaDeterminants.pdf?sequence=1\&isAllowe $\mathrm{d}=\mathrm{y}$.

Zingore, S., Delve, R. J., Nyamangara, J., and Giller, K. E. (2008). Multiple Benefits of Manure: The key to Maintenance of Soil Fertility and Restoration of Depleted Sandy Soils on African Smallholder Farms. Agroecosystem, 80, 267-282.

Zeller, M. (2000). Determinants of Credit Rationing: A Study of Informal Lenders and Formal Credit Groups in Madagascar. World Development, 22(12):1895-1907. 